\title{
ねじ推進へビ型ロボットの先頭追従制御
}

\author{
福島宏 明*1 田中基 康*2 亀 川哲 志*3 松 野 文 俊*1

\section{Front-Unit-Following Control of a Snake-like Robot \\ Using Screw Drive Mechanism}

Hiroaki Fukushima*1 $^{* 1}$ Motoyasu Tanaka ${ }^{* 2}$, Tetsushi Kamegawa*3 and Fumitoshi Matsuno*1

\begin{abstract}
This paper presents a front-unit-following control method for a snake-like robot using screw drive mechanism. The operators are required to command only one unit in the head, then commands for the rest of the units are automatically calculated to track the path of the preceding units. Asymptotic tracking error is investigated based on a Lyapunov approach for the case of a constant curvature. Furthermore, the effectiveness of the proposed method is investigated by computer simulations and laboratory experiments.
\end{abstract}

Key Words: Snake-like Robot, Screw Drive Mechanism, Path Tracking, Search and Rescue

1.はじめに

地震などで倒壊した建造物内の探索活動や, 床下・配管検査 などを目的としてへビ型ロボットの研究が精力的に行われてい る [1] [4].これらの多くは複数のクローラ車両を連結したも のであり，ロボットの上下でクローラの回転方向が異なるため, 天井の低い狭盆地では進入が難しいという課題が残されている. そのため, 上下に別々のクローラを配置し, 独立に駆動させる 機構を搭載したへビ型ロボットも開発されている [5] [6].

一方, ねじの原理に基づいた推進機構 [7]により, 体幹の周囲 $360^{\circ}$ のいずれかの点か環境に接していれば推進力を得ることが 可能なねじ推進へビ型ロボットの開発も進められている $[8] . こ$ のロボットは, 天井の低い狭隘地でねじ推進ユニットの上部と 下部の両方が環境に接した場合でも同じ方向に推進力を発生で きることに加えて, 全方向への推進も可能であるという特徵を もつ. 文献 [8]では, ねじ推進へビ型ロボットの運動学モデルを 導出し, 先頭ユニットの位置・姿勢, および各関節角度を与え られた目標軌道に追従させる制御系の設計を行っている。 とこ ろが, オペレータがヘビ型ロボットを遠隔操縦する際には, 先 頭ユニットの位置・姿勢に加え, すべての関節角に対して適切

\footnotetext{
原稿受付 2009 年 7 月 6 日

$* 1$ 京都大学大学院工学研究科

$* 2$ キヤノン株式会社

$* 3$ 岡山大学大学院自然科学研究科

${ }^{* 1}$ Graduate School of Engineering, Kyoto University

${ }^{* 2}$ Canon, Inc.

${ }^{* 3}$ Graduate School of Natural Science and Technology, Okayama University

ロ 本論文は学術性で評価されました。
}

に目標軌道を与えることが困難である場合が多い，特に，狭い 経路を移動する際には, 先頭のユニットの通った経路に後続の ユニットが追従するように関節を制御する必要があるため, こ れを自動で行うことができれば操縦の負担を大きく軽減できる と考えられる.

文献 [4] では, オペレータが先頭ユニットの速度指令のみを与 え, 後続ユニットは先頭ユニットの経路に自動的に追従するよ うな操縦システムの実装を行っている。 これに関連する研究と して多連結車両の経路追従制御 [9] [11] があるが, 目標経路か らの偏差をフィードバックする手法であるため, 先頭追従制御 に適用するためには先頭への過去の速度指令值から目標経路を 求める必要がある。これに対して, 文献 [4]の方法では現在時刻 の先頭への速度指令值のみに基づく方法であるため, アルゴリ ズムが簡略で実装が容易であり実験での有用性も報告されてい る、ところが, クローラ車両を連結したロボットを対象として いるため, 駆動原理が大きく異なるねじ推進へビ型ロボットに そのまま適用することは困難である，また，追従性能に関する 理論的な解析はまだ十分ではなく, 適用範囲が明らかでないの が現状である。

本論文では，ねじ推進へビ型ロボットの先頭追従制御手法を 提案する。この方法は運動学モデルに基づき, オペレータによっ て与えられた先頭ユニットの速度指令值を実現し, かつ後続の ユニットが先頭ユニットの経路を追従するための各ねじ推進ユ ニット，抢よび各関節の角速度を決定することを目的とする。 ま た,リアプノフ安定解析に基づき, 一定の曲率で前進する場合 には任意の初期状態から目標経路に収束することを示す。さら に, 目標経路の曲率が一定でない場合も含め, 数值例と実機実 験により提案手法の有効性を検証する。 


\section{2. ねじ推進へビ型ロボット}

本章では, 制御対象とする実験機と運動学モデルの概略を述 ベる [8].

\section{1 実験機の概略}

Fig. 1 にねじ推進へビ型ロボットの全体図を示す、ロボット を構成するねじ推進ユニットには右ねじ推進ユニットと左ねじ 推進ユニットの二つが存在し, 先頭から右ねじ推進ユニット, 左 ねじ推進ユニットの順に交互に四つのねじ推進ユニットを連結 した構成になっている。 また, ねじ推進ユニットは 2 自由度を 持つ関節ユニットにより直列に連結されており, 各関節の可動 範囲は $\pm \pi / 2[\mathrm{rad}]$ に制限されている。ただし，本研究ではピッ チ方向の関節を固定し，水平面上の運動のみに限定する.

Fig. 2 にねじ推進ユニットの概略図を示す.ねじ推進ユニッ トの中心を $o$ とし, $o-x y z$ をこの中心に固定した座標系とす る.また, ねじ推進ユニットの回転軸, すなわち $x$ 軸から受動 車輪の回転軸までの角度を $\alpha$ とする。 なお，Fig. 2 の左図では $\alpha$ が正, 右図では負となって扔り, それぞれ左ねじ推進ユニッ ト, 右ねじ推進ユニットと呼んでいる。受動車輪が横滑りしな いと仮定すると，スクリューを知印 A（Screw rotation）の方 向へ回転させたとき，ユニット中心部では矢印 B の方向に並進 速度を生じる。このとき, 受動車輪は矢印 C (Passive wheel rotation）の方向へ回転するため, 結果的にユニットの中心点 $o$ では, 受動車輪の回転軸方向 (Velocity of wheel) に速度が 発生する。

\section{2 運動学モデル}

Fig. 3 のように, $O-x y$ を絶対座標系とし, ロボット先頭 の制御点 $P$ の座標を $\left(x_{p} y_{p}\right)$, 先頭リンクの姿勢を $\psi_{p}$ とする. また, リンク $i$ のスクリュー部の中心の絶対座標系に関する位 置を $\left(x_{i}, y_{i}\right)$ とする. 各リンクの先端からねじ推進ユニット中 心までの距離を $L_{1}$, ねじ推進ユニット中心からリンク終端まで の距離を $L_{2}$ とする. ねじ推進ユニット $i$ の回転軸から受動車 輪の回転軸までの角度を $\alpha_{i}$, リンク $i$ とリンク $i+1$ のなす角 を関節角 $\phi_{i}$ とし, リンク $i$ の姿勢 $\psi_{i}$ を絶対座標系の $x$ 軸か らの偏角とする. すなわち, $\psi_{i}=\psi_{p}+\sum_{k=1}^{i-1} \phi_{k}(i=2,3,4)$ であ る. また, ねじ推進ユニット $i$ の回転角速度を $\dot{\theta}_{i}(i=1,2,3,4)$ とする.

まず，幾何学的な関係から，第 $i$ リンクのスクリュー部の中 心の位置座標は以下のように与えられる。

$$
\begin{aligned}
& x_{i}=x_{p}+L_{1} \cos \psi_{p}+\sum_{j=1}^{i-1}\left(L_{2} \cos \psi_{j}+L_{1} \cos \psi_{j+1}\right) \\
& y_{i}=y_{p}+L_{1} \sin \psi_{p}+\sum_{j=1}^{i-1}\left(L_{2} \sin \psi_{j}+L_{1} \sin \psi_{j+1}\right)
\end{aligned}
$$

次に，式（1）の時間微分を受動車輪の速度拘束式

$$
\dot{x}_{i} \cos \left(\alpha_{i}+\psi_{i}\right)+\dot{y}_{i} \sin \left(\alpha_{i}+\psi_{i}\right)+r \dot{\theta}_{i} \sin \alpha_{i}=0
$$

に代入する。ここで, $r$ は Fig. 2 のように, ねじ推進ユニット の半径（ユニットの中心から接地点までの距離）とする。この

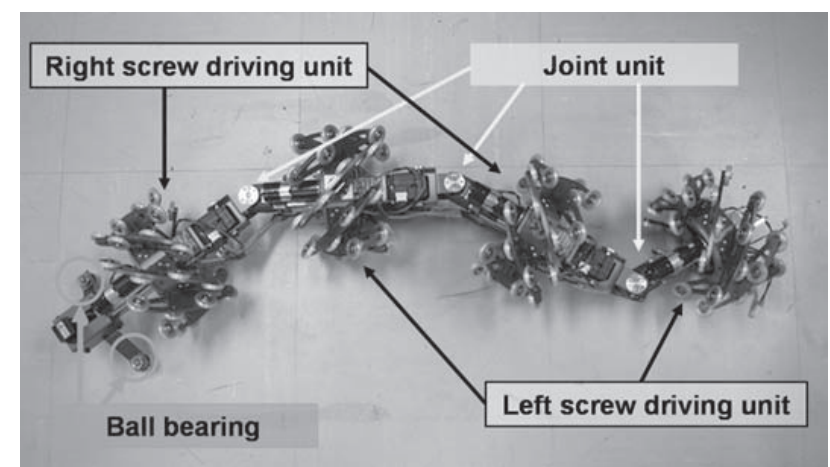

Fig. 1 Snake-like robot using screw drive mechanism

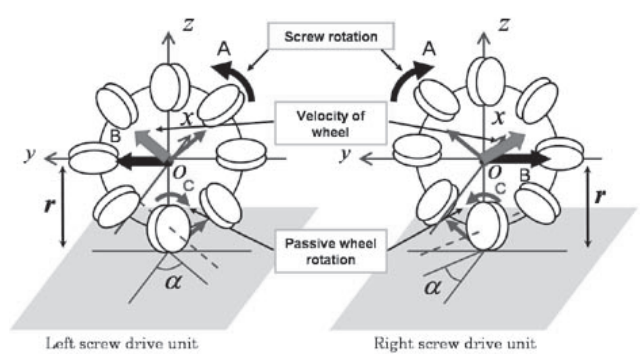

Fig. 2 Schematic of left and right screw drive units

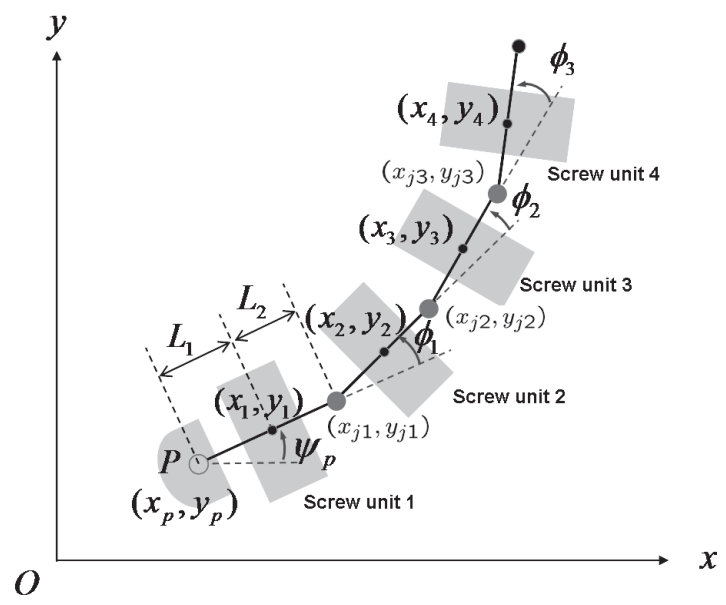

Fig. 3 Schematic of a screw drive snake-like robot

とき, 運動学モデルは次のように導ける.

$$
A \dot{w}=B u
$$

ただし, $w:=\left[\begin{array}{llllll}x_{p} & y_{p} & \psi_{p} & \phi_{1} & \phi_{2} & \phi_{3}\end{array}\right]^{T}$ は被制御量, $u:=$ $\left[\begin{array}{lllllll}\dot{\theta}_{1} & \dot{\theta}_{2} & \dot{\theta}_{3} & \dot{\theta}_{4} & \dot{\phi}_{1} & \dot{\phi}_{2} & \dot{\phi}_{3}\end{array}\right]^{T}$ は入力であり, $A$ と $B$ は次式で 定義される。

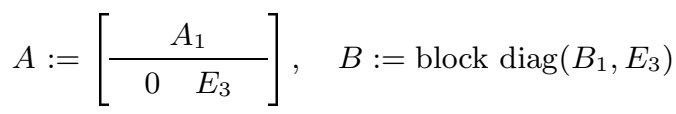

$$
\begin{aligned}
& A_{1}:=\left[\begin{array}{cccccc}
a_{11} & a_{12} & a_{13} & 0 & 0 & 0 \\
a_{21} & a_{22} & a_{23} & a_{24} & 0 & 0 \\
a_{31} & a_{32} & a_{33} & a_{34} & a_{35} & 0 \\
a_{41} & a_{42} & a_{43} & a_{44} & a_{45} & a_{46}
\end{array}\right] \\
& B_{1}:=-r \operatorname{diag}\left(\sin \alpha_{1}, \sin \alpha_{2}, \sin \alpha_{3}, \sin \alpha_{4}\right)
\end{aligned}
$$


$a_{i 1}:=\cos \left(\alpha_{i}+\psi_{i}\right), \quad a_{i 2}:=\sin \left(\alpha_{i}+\psi_{i}\right)$

$a_{13}:=L_{1} \sin \alpha_{1}, \quad a_{23}:=L_{1} \sin \left(\alpha_{2}+\phi_{1}\right)+L_{1} \sin \alpha_{2}$

$a_{24}:=L_{1} \sin \alpha_{2}, \quad a_{33}:=L_{1} \sin \left(\alpha_{3}+\phi_{1}+\phi_{2}\right)+a_{34}$

$a_{34}:=L \sin \left(\alpha_{3}+\phi_{2}\right)+L_{1} \sin \alpha_{3}, \quad a_{35}:=L_{1} \sin \alpha_{3}$

$a_{43}:=L \sin \left(\alpha_{4}+\phi_{1}+\phi_{2}+\phi_{3}\right)+a_{44}$

$a_{44}:=L \sin \left(\alpha_{4}+\phi_{2}+\phi_{3}\right)+a_{45}$

$a_{45}:=L \sin \left(\alpha_{4}+\phi_{3}\right)+L_{1} \sin \alpha_{4}, \quad a_{46}:=L_{1} \sin \alpha_{4}$

ここで, $L:=L_{1}+L_{2}, E_{k}$ は $k \times k$ の単位行列である. なお, 本研究で用いる実験機では, 各物理パラメー夕の值は $L_{1}=0.103[\mathrm{~m}], L_{2}=0.123[\mathrm{~m}], r=0.075[\mathrm{~m}], \alpha_{i}=$ $-\pi / 4[\mathrm{rad}](i=1,3), \alpha_{i}=\pi / 4[\mathrm{rad}](i=2,4)$ となっている.

\section{3. 先頭追従制御則}

操縦者により, ロボットの先頭リンクの並進速度 $v_{1}(t)$ と回 転速度 $\omega_{1}(t)$ が与えられるものとする，ただし，本研究ではロ ボットが前進する場合のみを考えるため， $v_{1}<0$ となる.

本研究の目的は, 操縦者によって与えられた先頭ユニットの 速度指令值

$$
\dot{x}_{p}=v_{1} \cos \psi_{p}, \quad \dot{y}_{p}=v_{1} \sin \psi_{p}, \quad \dot{\psi}_{p}=\omega_{1}
$$

を達成し, かつ後続ユニットを先頭 $P$ が通った経路に沿って追 従させる制御入力 $u$ を決定することである，ただし，Fig. 4 の ように, 先頭リンクの姿勢 $\psi_{p}$ は定義より常に $P$ の経路 $\gamma^{\prime}$ の 接線方向に一致するため, 先頭リンクの終点である第 1 関節の 位置は $\gamma^{\prime}$ が直線であるなどの特殊な場合を除いて $\gamma^{\prime}$ から外れ てしまう。したがって，より正確には第 1 関節が通った軌道 $\gamma$ に沿って後続の関節を追従させる問題を考える.

\section{1 先頭追従を実現する各関節の移動速度}

初期時刻 $t=0$ において, 第 2 関節以降の座標 $\left(x_{j 2}, y_{j 2}\right)$, $\left(x_{j 3}, y_{j 3}\right),\left(x_{j 4}, y_{j 4}\right)$ が第 1 関節が通った軌道 $\gamma$ 上に位置して いると仮定する。このとき, 第 2 関節以降の移動速度を常に軌 道 $\gamma$ の接線方向に発生させることにより, 各関節を軌道 $\gamma$ に 追従させることが可能である.

先頭に式 (4) の速度が与えられたとすると, 幾何学的な関係

$$
x_{j 1}=x_{p}+L \cos \psi_{p}, \quad y_{j 1}=y_{p}+L \sin \psi_{p}
$$

から第 1 関節の移動速度は

$$
\begin{aligned}
\dot{x}_{j 1} & =\dot{x}_{p}-L \dot{\psi}_{p} \sin \psi_{p} \\
\dot{y}_{j 1} & =\dot{y}_{p}+L \dot{\psi}_{p} \cos \psi_{p}
\end{aligned}
$$

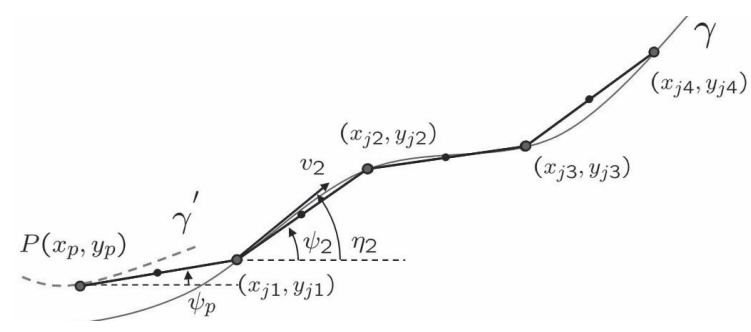

Fig. 4 Trajectory of each joint
となる.このとき, 第 $i$ 関節 $(i=2,3)$ の位置 $\left(x_{j i}, y_{j i}\right)$ にお ける軌道 $\gamma$ の接線の絶対角を $\eta_{i+1}$ とすると, 第 $i$ 関節の並進 速度 $v_{i+1}$, 回転速度 $\dot{\psi}_{i}$ は

$$
\begin{aligned}
& \dot{x}_{j i}=\dot{x}_{j(i-1)}-L \dot{\psi}_{i} \sin \psi_{i}=v_{i+1} \cos \eta_{i+1} \\
& \dot{y}_{j i}=\dot{y}_{j(i-1)}+L \dot{\psi}_{i} \cos \psi_{i}=v_{i+1} \sin \eta_{i+1}
\end{aligned}
$$

の関係を満たせばよいことが分かる。したがって, 式（7）を解 くことにより先頭追従を実現する $\dot{\psi}_{i}$ と $v_{i+1}$ は

$$
\begin{aligned}
\dot{\psi}_{i} & =\frac{\dot{x}_{j(i-1)} \sin \eta_{i+1}-\dot{y}_{j(i-1)} \cos \eta_{i+1}}{L \cos \left(\psi_{i}-\eta_{i+1}\right)} \\
v_{i+1} & =\frac{\dot{x}_{j(i-1)} \cos \psi_{i}+\dot{y}_{j(i-1)} \sin \psi_{i}}{\cos \left(\psi_{i}-\eta_{i+1}\right)}
\end{aligned}
$$

となる. なお, 第 $i$ 関節の座標 $\left(x_{j i}, y_{j i}\right)$ は第 $i-1$ 関節が過去 に通った位置であることから， $\eta_{i+1}$ は $\eta_{i}$ の過去の值に等しい. 例えば, $\eta_{3}(t)$ は $\eta_{2}:=\tan ^{-1}\left(\dot{y}_{j 1} / \dot{x}_{j 1}\right)$ の過去の值 $\eta_{2}(t-\sigma)$ に等しく, $\sigma$ は以下の関係を満たす正数

$$
\int_{\tau=0}^{\sigma} v_{j 1}(t-\tau) \cos \left(\eta_{2}(t-\tau)-\psi_{2}(t)\right) d \tau=L
$$

すなわち第 1 関節の過去の並進速度 $v_{j 1}(t-\tau)$ のリンクに沿っ た成分を積分して得られる距離が $L$ となる時間である。ただ し, $v_{j 1}:=\sqrt{\dot{x}_{j 1}^{2}+\dot{y}_{j 1}^{2}}$ である.したがって, $\eta_{i+1}$ を求めるた めには, $\left(\dot{x}_{j 1}, \dot{y}_{j 1}\right)$ のような過去のデータを保存しておく必要 がある。 また, 式（9）を満たす $\sigma$ を数值的に求めるには計算 量が大きく，実装は困難な場合が多い.

本論文では過去のデータを用いない簡略な制御則を提案する。 3.2 節で述べるように, 提案する制御則は, 軌道の曲率が連続 的に変化する場合に, リンクが短くなるに従って $\left(v_{i}, \dot{\psi}_{i}\right)$ が式 （7）の解, すなわち式（8）に収束するように決定される.

\section{2 制御入力の決定}

3.1 節と同様に, 初期時刻で各関節が目標経路 $\gamma$ 上にあると 仮定する (Fig. 4 参照). 軌道の曲率が連続的に変化する場合, リンクが短くなるにしたがって, 各関節間で軌道は曲率の変化 が小さくなり，Fig.5のように円弧とみなすことができる.こ のとき, 幾何学的な関係より

$$
\eta_{i+1}-\psi_{i}=\psi_{i}-\eta_{i}
$$

が成り立つ。また，式（7）より

$$
\begin{aligned}
v_{i+1} \cos \left(\eta_{i+1}-\psi_{i}\right) & =\dot{x}_{j i} \cos \psi_{i}+\dot{y}_{j i} \sin \psi_{i} \\
& =\dot{x}_{j(i-1)} \cos \psi_{i}+\dot{y}_{j(i-1)} \sin \psi_{i} \\
& =v_{i} \cos \left(\psi_{i}-\eta_{i}\right)
\end{aligned}
$$

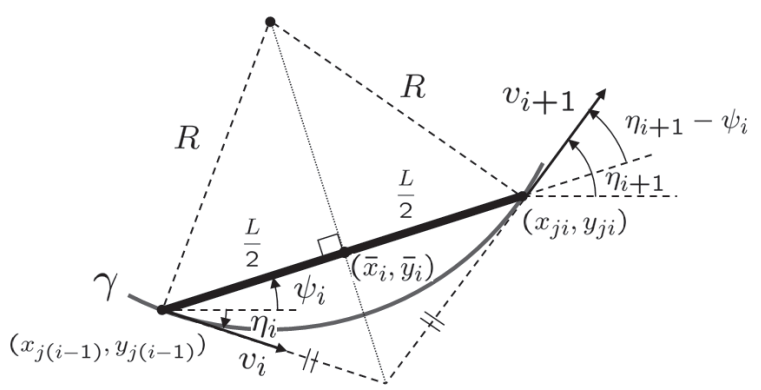

Fig. 5 Velocity of links 
となるため，式（10）より $v_{i+1}=v_{i}$ となることが分かる。 し たがって,リンクの中点 $\left(\bar{x}_{i}, \bar{y}_{i}\right)$ ではリンクに沿った並進速度 が発生する，すなわち，中点の並進速度を $\bar{v}_{i}$ とすると

$$
\begin{aligned}
& \dot{\bar{x}}_{j i}=\dot{x}_{j(i-1)}-\frac{L}{2} \dot{\psi}_{i} \sin \psi_{i}=\bar{v}_{i} \cos \psi_{i} \\
& \dot{\bar{y}}_{j i}=\dot{y}_{j(i-1)}+\frac{L}{2} \dot{\psi}_{i} \cos \psi_{i}=\bar{v}_{i} \sin \psi_{i}
\end{aligned}
$$

が成り立つ。この連立方程式を解くことにより

$$
\begin{aligned}
\dot{\psi}_{i} & =\frac{2}{L}\left\{\dot{x}_{j(i-1)} \sin \psi_{i}-\dot{y}_{j(i-1)} \cos \psi_{i}\right\} \\
\bar{v}_{i} & =\dot{x}_{j(i-1)} \cos \psi_{i}+\dot{y}_{j(i-1)} \sin \psi_{i}
\end{aligned}
$$

を得る。な挹, $\phi_{1}=\psi_{2}-\psi_{p}$ の関係と式 $(4) \sim(6)$ より, $\dot{\phi}_{1}$ と $\bar{v}_{2}$ は次のように表せる.

$$
\begin{aligned}
& \dot{\phi}_{1}=\frac{2}{L} v_{1} \sin \phi_{1}-\omega_{1}\left(2 \cos \phi_{1}+1\right) \\
& \bar{v}_{2}=v_{1} \cos \phi_{1}+L \omega_{1} \sin \phi_{1}
\end{aligned}
$$

また，式（13）より $\dot{\phi}_{2}$ と $\bar{v}_{3}$ は

$$
\begin{aligned}
\dot{\phi}_{2} & =\frac{2}{L} \bar{v}_{2} \sin \phi_{2}-\left(\omega_{1}+\dot{\phi}_{1}\right)\left(\cos \phi_{2}+1\right) \\
\bar{v}_{3} & =\bar{v}_{2} \cos \phi_{2}+\frac{L}{2}\left(\omega_{1}+\dot{\phi}_{1}\right) \sin \phi_{2}
\end{aligned}
$$

となる。同様に $\dot{\phi}_{3}$ は

$$
\dot{\phi}_{3}=\frac{2}{L} \bar{v}_{3} \sin \phi_{3}-\left(\omega_{1}+\dot{\phi}_{1}+\dot{\phi}_{2}\right)\left(\cos \phi_{3}+1\right)
$$

となる。したがって, 式（3）の制御入力 $u$ において $\dot{\phi}_{1}, \dot{\phi}_{2}$, $\dot{\phi}_{3}$ は先頭速度の指令值 $\left(v_{1}, \omega_{1}\right)$ と関節角 $\phi_{i}$ から逐次的に決定 できることが分かる。.さらに，得られた $\dot{\phi}_{1}, \dot{\phi}_{2}, \dot{\phi}_{3}$ を, 式 (4) で表される先頭の速度 $\left(\dot{x}_{p} \dot{y}_{p} \dot{\psi}_{p}\right)$ とともに式 (3) の運動学乇 デルに代入する。 このとき, 式（3）の上 4 行が $\dot{\theta}_{1}, \dot{\theta}_{2}, \dot{\theta}_{3}, \dot{\theta}_{4}$ に対する連立方程式となり, 制御入力 $u$ を一意に求めることが できる。

\section{4. 目標経路への収束性に関する考察}

3 章では，初期時刻で各関節が目標経路 $\gamma$ 上にあること，お よび各関節間で $\gamma$ の曲率が一定とみなせることを仮定して制御 則を導出した。これは $\gamma$ が急激に変化すると追従誤差が生じる ことを意味している，そのため, ある時刻で追従誤差が生じた 場合に目標経路 $\gamma$ に収束するための条件を求めることが重要で ある，本章では，初期時刻で各関節が目標経路から外れている 場合にも, 先頭に対する速度指令值 $\left(v_{1}, \omega_{1}\right)$ が一定であれば目 標経路 $\gamma$ に収束することを示す。 なお，ここでは $\omega_{1}<0$ の場 合を示すが, $\omega_{1}>0$ の場合も同様に議論できる. また, $\gamma$ が直 線となる $\omega_{1}=0$ の場合も示すことが可能であるが，簡単なの でここでは省略する。

まず，式（4）の積分から,

$$
x_{p}=C_{x}+R_{p} \sin \psi_{p}, \quad y_{p}=C_{y}-R_{p} \cos \psi_{p}
$$

となる。ただし， $R_{p}:=v_{1} / \omega_{1}$ であり

$$
C_{x}:=x_{0}-R_{p} \sin \psi_{0}, \quad C_{y}:=y_{0}+R_{p} \cos \psi_{0}
$$

とする.また, $\left(x_{0}, y_{0}, \psi_{0}\right)$ は $\left(x_{p}, y_{p}, \psi_{p}\right)$ の初期值である.よっ て, 式 (5) の関倸から第 1 関節に対して

$$
\begin{aligned}
& x_{j 1}=C_{x}+R_{j 1} \sin \left(\psi_{p}+\alpha_{j 1}\right) \\
& y_{j 1}=C_{y}-R_{j 1} \cos \left(\psi_{p}+\alpha_{j 1}\right)
\end{aligned}
$$

が成立する，ただし， $R_{j 1}=\sqrt{R_{p}^{2}+L^{2}}$ であり， $\alpha_{j 1}$ は

$$
\cos \alpha_{j 1}=\frac{R_{p}}{R_{j 1}}, \quad \sin \alpha_{j 1}=\frac{L}{R_{j 1}}
$$

を満たす值である。ここでは $L>0, R_{p}>0$ より，一般性を 失わず $0<\alpha_{j 1}<\pi / 2$ とする. したがって, 式 (19) より, 第 1 関節は $\left(C_{x}, C_{y}\right)$ を中心とした半径 $R_{j 1}$ の円軌道となること が分かる。また，式（14）より

$$
\dot{\phi}_{1}=\frac{2 R_{j 1} \omega_{1}}{L} \sin \left(\phi_{1}-\alpha_{j 1}\right)-\omega_{1}
$$

となる. いま, $\Phi_{1}:=\dot{\phi}_{1}$ と定義すると, 正定関数 $V_{1}=\Phi_{1}{ }^{2} / 2$ に対して

$$
\dot{V}_{1}=\Phi_{1} \cdot \dot{\Phi}_{1}=\Phi_{1}^{2} \frac{2 R_{j 1} \omega_{1}}{L} \cos \left(\phi_{1}-\alpha_{j 1}\right)
$$

となる，ここで，関節の可動範囲は $-\pi / 2 \leq \phi_{1} \leq \pi / 2$ であ るので, 以下では $-\pi / 2 \leq \phi_{1} \leq 0$ と $0 \leq \phi_{1} \leq \pi / 2$ の場合 に分けて考光る. まず, $-\pi / 2 \leq \phi_{1} \leq 0$ の場合, 式（21）と $\omega_{1}<0,0<\alpha_{j 1}<\pi / 2$ より, $\dot{\phi}_{1}>-\omega_{1}>0$ となり, 有限時間 で $0 \leq \phi_{1} \leq \pi / 2$ となる. したがって, 以下では $0 \leq \phi_{1} \leq \pi / 2$ の場合のみを考元る。このとき, $-\pi / 2<\phi_{1}-\alpha_{j 1}<\pi / 2$ であるので, $\cos \left(\phi_{1}-\alpha_{j 1}\right)>0$ となる. よって, 式 $(22)$ よ り $\dot{V}_{1}<0\left(\forall \Phi_{1} \neq 0\right)$ となるため, リアプノフの定理より $\Phi_{1}=\dot{\phi}_{1} \rightarrow 0$ となる. したがって, 式 (21) より $\phi_{1}$ は可動範 囲内で以下のように収束する。

$$
\phi_{1} \rightarrow \sin ^{-1} \frac{L}{2 R_{j 1}}+\alpha_{j 1}(t \rightarrow \infty)
$$

同様の考え方により, $\phi_{i}(i=2,3)$ において,

$$
\phi_{2} \rightarrow 2 \sin ^{-1} \frac{L}{2 R_{j 1}}, \quad \phi_{3} \rightarrow 2 \sin ^{-1} \frac{L}{2 R_{j 1}}
$$

となる (詳細は付録 $\mathrm{A}$ 参照).

Fig. 6 は式（23）（24）から得られるロボットの漸近的な配 置を示している. 先頭ユニットの姿勢角 $\psi_{p}$ は常に先頭 $P$ の経 路の接線方向に対応しているので, $\angle O_{r} P A=\pi / 2$ が成り立つ. したがって, 式 (20) から $\angle O_{r} A P=\pi / 2-\alpha_{j 1}$ となるので, $\angle O_{r} A B=\pi / 2-\phi_{1}+\alpha_{j 1}$ が得られる.これより, $O_{r}$ から $\overline{A B}$ への垂線の足を $M_{2}$ とすると, $\angle A O_{r} M_{2}=\phi_{1}-\alpha_{j 1}$ が成り立 つ.また, 式 (23) より $\overline{A M_{2}}=R_{j 1} \sin \left(\phi_{1}-\alpha_{j 1}\right)=L / 2$ で あるので, $M_{2}$ は $\overline{A B}$ の中点となり, $\triangle O_{r} A M_{2} \equiv \triangle O_{r} B M_{2}$ となる. よって, $\triangle O_{r} A B$ は $\overline{O A}=\overline{O B}$ の二等辺三角形とな るので, 第 1 関節と第 2 関節は半径 $R_{j 1}$ の同一円上にあること が分かる. また, $\angle O_{r} A B=\angle O_{r} B A=\pi / 2-\phi_{1}+\alpha_{j 1}$ から $\angle O_{r} B C=\pi / 2-\phi_{2}+\phi_{1}-\alpha_{j 1}$ が成り立つ. これにより, $O_{r}$ 


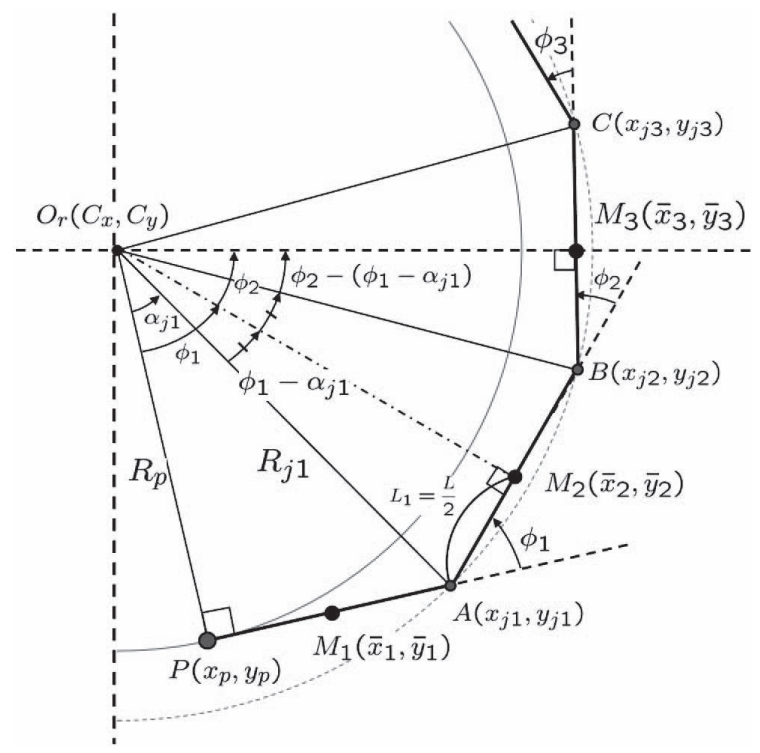

Fig. 6 Asymptotic configuration for a constant curvature

から $\overline{B C}$ への垂線の足に対して $\angle B O_{r} M_{3}=\phi_{2}-\phi_{1}+\alpha_{j 1}$ と なる。ここで，式（23）（24）から

$$
\begin{aligned}
\overline{B M}_{3} & =R_{j 1} \sin \left(\phi_{2}-\left(\phi_{1}-\alpha_{j 1}\right)\right) \\
& =R_{j 1} \sin \left(2 \sin ^{-1}\left(\frac{L}{2 R_{j 1}}\right)-\sin ^{-1}\left(\frac{L}{2 R_{j 1}}\right)\right)=\frac{L}{2}
\end{aligned}
$$

となるので， $M_{3}$ は $\overline{B C}$ の中点となることが分かる．したがっ て, $\triangle O_{r} B C$ は $\overline{O B}=\overline{O C}$ の二等辺三角形となるので，第 3 関節は第 1 関節，第 2 関節と同一円上にある。ささらに，式 $(24)$ より $\phi_{2}=\phi_{3}$ となり, 第 4 リンク最後尾に関しても, 同様に半 径を $R_{j 1}$ とする同一円上にあることを示すことができる.

なお，直線や円軌道以外に対する収束性に関して数学的に証 明することは困難であり，この場合には定常的に追従誤差が残る 可能性がある. 目標経路が直線や円軌道であれば，例えば Fig. 6 から幾何学的に関節の目標角度を決定し, 文献 [8] の方法を用 いて制御することも可能であるが, 本論文の提案手法はこのよ うな方法とは異なる。 3.2 節では, 隣り合う二つの関節位置の 目標経路が円弧であることを仮定して制御則を導いているため, 目標経路が円弧でなくても, 曲率の変化に対してリンク長が小 さければ仮定が満たされ，追従誤差が小さく抑えられることが 期待できる. 5,6 章では, 円弧以外の経路についても提案手法 を適用し, 経路の曲率変化と追従誤差の関倸について考察する。

\section{5. 数 值 例}

本章では提案した先頭追従制御手法に基づいて計算機シミュ レーションを行い, 提案手法の有効性を検証する.

まず, 先頭の制御点 $P$ の並進速度指令值を $v_{1}=-\pi / 60[\mathrm{~m} / \mathrm{s}]$ とし, 先頭リンクの回転速度指令值は時刻 $t=30[\mathrm{~s}]$ までを $\omega_{1}=-\pi / 30[\mathrm{rad} / \mathrm{s}]$, それ以降は $\omega_{1}=\pi / 30[\mathrm{rad} / \mathrm{s}]$ に切り替 える. したがって, $P$ の目標経路は半径 $0.5[\mathrm{~m}]$ の円弧を連結し た経路となる，4 章で述べたように, 先頭 $P$ の経路が半径 $R_{p}$

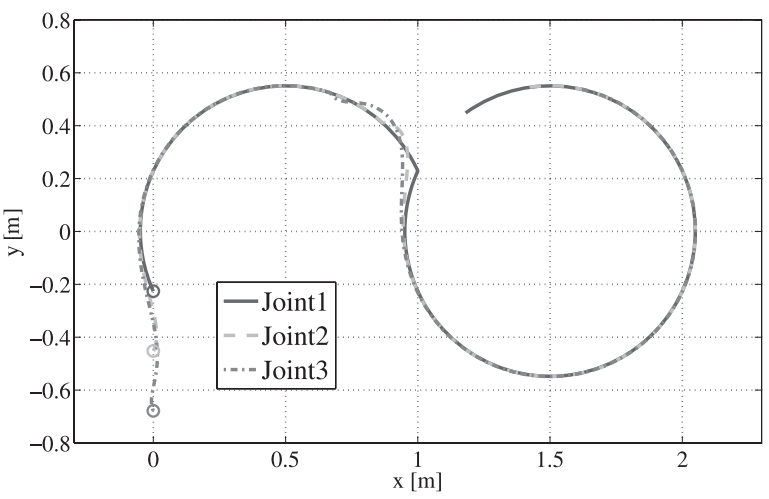

Fig. $7 \quad x-y$ plot of each joint path (simulation)

Table 1 Tracking error for $\omega_{1}=-(\pi / 30) \cos (\lambda \pi t / 60)$

\begin{tabular}{|c|c|c|c|c|}
\hline & $\lambda=0.5$ & $\lambda=1$ & $\lambda=1.5$ & $\lambda=2$ \\
\hline$\left(x_{j 2}, y_{j 2}\right)$ & $1.22 \times 10^{-3}$ & $1.98 \times 10^{-3}$ & $2.99 \times 10^{-3}$ & $4.07 \times 10^{-3}$ \\
$\left(x_{j 3}, y_{j 3}\right)$ & $2.35 \times 10^{-3}$ & $3.92 \times 10^{-3}$ & $5.94 \times 10^{-3}$ & $8.07 \times 10^{-3}$ \\
$\left(x_{j 4}, y_{j 4}\right)$ & $3.34 \times 10^{-3}$ & $5.80 \times 10^{-3}$ & $8.81 \times 10^{-3}$ & $1.20 \times 10^{-2}$ \\
\hline
\end{tabular}

の円である場合には, 第 1 関節の経路は同じ点を中心とする半径 $\sqrt{R_{p}^{2}+L^{2}}$ の円となる. 初期状態 $w(0)=[0,0,3 \pi / 2,0,0,0]^{T}$ に対する $t=85[\mathrm{~s}]$ までの各関節の経路を Fig. 7 に示す. 実 線, 破線, 一点鎖線はそれぞれ第 1 , 第 2 , 第 3 関節の経路を 表しておうり,「○」は各関節の初期位置を表している。初期時刻 $t=0$ に扔いてロボットの形状は直線状であり, 第 2 , 第 3 関 節は目標の円軌道上にないため誤差が生じているが, 時間の経 過とともに誤差が小さくなり, 先頭の目標角速度が切り替わる 時刻 $t=30[\mathrm{~s}]$ までは第 1 関節と同じ経路をたどっている。 ま た, 時刻 $t=30[\mathrm{~s}]$ で第 1 関節の経路は座標 $(1,0.25)$ 付近で曲 率が不連続に変化するため, 第 2 , 第 3 関節が目標である第 1 関節の経路から外れているが, 4 章で述べたように, 曲率が一 定になると目標経路に収束しているのが分かる。

次に, 曲率が常に変化する場合の経路追従誤差の大きさを 評価するため, 先頭の並進速度指令值を $v_{1}=-\pi / 60[\mathrm{~m} / \mathrm{s}]$, 先頭リンクの回転速度指令值を定数 $\lambda$ に対して $\omega_{1}=$ $-(\pi / 30) \cos (\lambda \pi t / 60)[\mathrm{rad} / \mathrm{s}]$ としてシミュレーションを行 う.このとき, $\omega_{1}$ は $60 / \lambda[\mathrm{s}]$ の間に $-\pi / 30[\mathrm{rad} / \mathrm{s}]$ から $\pi / 30[\mathrm{rad} / \mathrm{s}]$ に滑らかに切り替わる. Table 1 に $\lambda=$ $0.5 ， 1 ， 1.5 ， 2$ に対する経路追従誤差の最大值を示す。これ により, 例えば $\lambda=1$ 以内であれば各関節の経路追従誤差は $5.80 \times 10^{-3}[\mathrm{~m}]$, すなわち体幹の幅 $2 r=0.15[\mathrm{~m}]$ の $4 \%$ 以内 に収まることが分かる。 また，この表から最大誤差は $\lambda$ に対し てほぼ線形に増加する傾向があることが分かる。なお，ここで は一般的な関数として三角関数を用いて先頭の速度指令值を変 化させた経路を用いたが，実際にオペレータが操縦する際に与 える先頭の速度指令值を想定した誤差の解析までには至ってい ないのが現状であり，今後の課題である.

\section{6. 実 機 実 験}

本章では提案した先頭追従制御手法の有効性を, 実機実験に より検証する，構築した実験環境ではオペレータが市販のゲー 


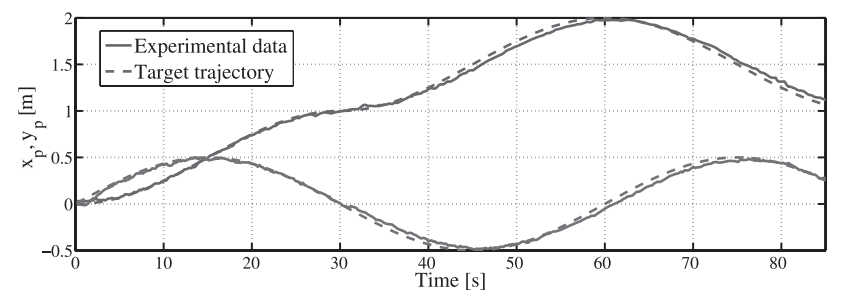

Fig. 8 Time plot of $x_{p}$ and $y_{p}$ (experiment)

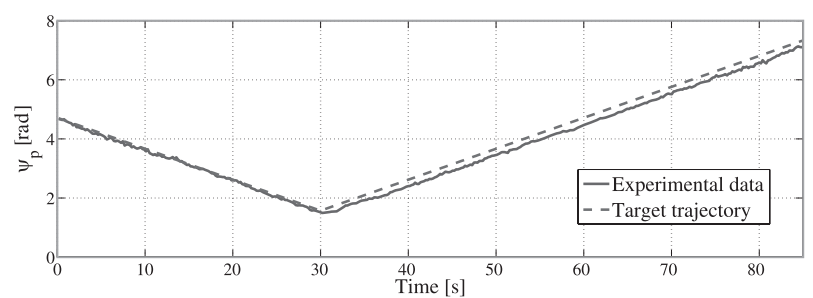

Fig. 9 Time plot of $\psi_{p}$ (experiment)

ム機のコントローラを使って操縦することも可能であるが, こ こでは前章の数值例との比較のため, あらかじめ生成した速度 指令值を与える。ただし, 実機実験の場合にはモデル化誤差や 外乱の影響があるため, オペレータが操縦する際と同様にロボッ トの先頭の動きに合わせて速度指令值を修正する必要がある。 そこで, 三次元位置計測装置 QuickMag IV（(株）応用計測研 究所）により計測した先頭の位置姿勢 $\left(x_{p}^{e x p}, y_{p}^{e x p}, \psi_{p}^{e x p}\right)$ を用 いて, 先頭への指令值 $\left(\dot{x}_{p}, \dot{y}_{p}, \dot{\psi}_{p}\right)$ を次のように修正する.

$$
\begin{aligned}
\dot{x}_{p}^{\prime} & =\dot{x}_{p}+k_{x}\left(x_{p}-x_{p}^{e x p}\right) \\
\dot{y}_{p}^{\prime} & =\dot{y}_{p}+k_{y}\left(y_{p}-y_{p}^{e x p}\right) \\
\dot{\psi}_{p}^{\prime} & =\dot{\psi}_{p}+k_{\psi}\left(\psi_{p}-\psi_{p}^{e x p}\right)
\end{aligned}
$$

ただし， $k_{x}=k_{y}=1, k_{\psi}=0.5$ である。

前章と同様に, まず, 先頭の制御点 $P$ の並進速度指令值 を $v_{1}=-\pi / 60[\mathrm{~m} / \mathrm{s}]$ とし, 先頭リンクの回転速度指令值 は時刻 $t=30[\mathrm{~s}]$ までを $\omega_{1}=-\pi / 30[\mathrm{rad} / \mathrm{s}]$, それ以降は $\omega_{1}=\pi / 30[\mathrm{rad} / \mathrm{s}]$ に切り替えたときの先頭の位置・姿勢の時間 応答をそれぞれ Fig. 8 と Fig. 9 に示す. 実線が計測值, 破線 が目標軌道 $\left(x_{p}, y_{p}, \psi_{p}\right)$ である. 使用した実験機は特に反時計 周りの旋回の際にモデル化誤差が大きく, 実際の速度が指令值 と顕著に異なる傾向があるが, 式（26）のように速度指令值を 修正することにより，Fig. 8 と Fig. 9 において時刻 $t=30[\mathrm{~s}]$ 以降でも目標軌道からの誤差が小さく抑えられている。このよ うな条件の下で得られた関節の経路の $x-y$ プロットを Fig. 10 に示す．実線，破線，一点鎖線はそれぞれ第 1 , 第 2 , 第 3 関節 の経路を表しており，「○」は各関節の初期位置を表している. Fig. 10 より, 前章の数值例における Fig. 7 の経路がおおむね実 現されていることが分かる.ただし, 数值例では定常状態で第 2 ・第 3 関節の経路は第 1 関節の経路に誤差なく追従していた のに対して, 特に反時計回りに旋回する場合に最大で $5[\mathrm{~cm}]$ 近 い誤差が生じている。この原因として，モデルで考慮すること が困難な受動車輪の横滑り, ロボットのロール方向へのねじれ, 通信ケーブルによる負荷のほか, 特に反時計回りに旋回する場 合には先頭の位置・姿勢誤差の影響で第 1 関節が数值例よりも

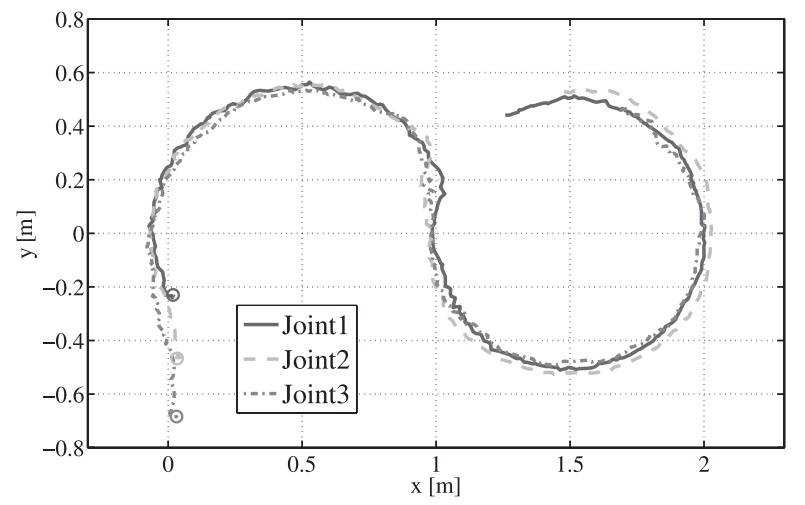

Fig. $10 x-y$ plot of each joint path (experiment)

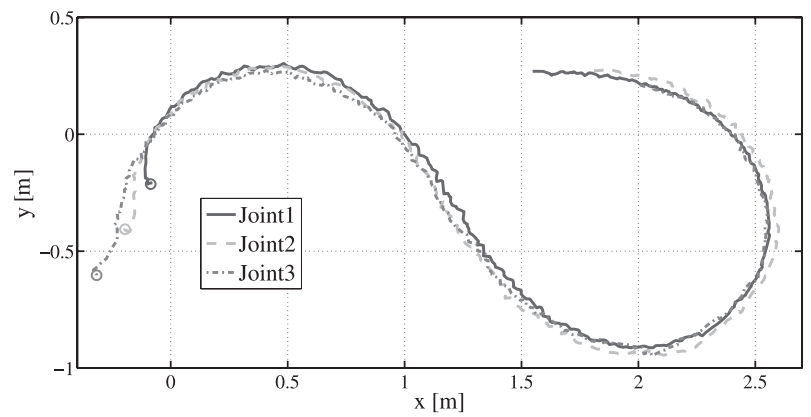

Fig. $11 x-y$ plot for $\omega_{1}=-\pi / 30 \cos \pi / 60 t$ (experiment)

半径が $5[\mathrm{~cm}]$ 程度小さい円弧に追従している影響が考えられる.

次に, 先頭の並進速度指令值を $v_{1}=-\pi / 60[\mathrm{~m} / \mathrm{s}]$, 先 頭リンクの回転速度指令值を $\lambda=1$ に対して $\omega_{1}=$ $-(\pi / 30) \cos (\lambda \pi t / 60)[\mathrm{rad} / \mathrm{s}]$ のように変化させた場合の例を 示す. Fig. 11 は初期状態 $w(0)=[0,0,5 \pi / 3,0,0,0]^{T}$ に対す る $t=95[\mathrm{~s}]$ までの各関節の経路の $x-y$ プロットを示してい る. 数值例では Table 1 のように経路追従誤差が $4[\mathrm{~mm}]$ ほど であったのに対して，実機実験では円軌道の例と同様に $5[\mathrm{~cm}]$ 程度の誤差が生じている. 今後, このようなモデルの誤差に対 処するための制御手法を検討する必要があると考えられる.

\section{7.おわりに}

本論文では, ねじ推進へビ型ロボットの運動学モデルに基づ き, オペレータによって与えられた先頭ユニットの速度指令值を 実現し, かつ後続のユニットが先頭ユニットの経路を追従させ ることを目的とした先頭追従制御手法を提案した。また，リア プノフ安定解析に基づき, 一定の曲率で前進する場合には任意 の初期状態から目標経路に収束することを示した。ささらに，目 標経路の曲率が一定でない場合も含め, 数值例と実機実験によ り提案手法の有効性を検証した。今後は実際にオペレータが操 縦する際に与える先頭の速度指令值を想定し, 様々な経路に対 して追従性能の解析を行っていく必要がある。また, 受動車輪 の横滑りなどの不確かさに対処できる自己位置推定・制御手法 の検討, および斜面や不整地における三次元での運動解析も今 後の課題である。なお, 本研究は文部科学省科学研究費 (基盤 B20360107）によって行われたものである，また，実験環境の 
構築においてご協力いただいた原正哉氏（株式会社オリエンタ ルランド）に謝意を表する。

\section{参 考 文 献}

[1] 広瀬茂男, 松野文俊：“レスキュー用ヘビ型ロボットの開発一形態設 計とその制御—”, 日本機械学会誌, vol.106, no.1019, pp.769-773, 2003.

[2] S. Hirose, H. Ohno, T. Mitsui and K. Suyama: "Design and Experiments of In-pipe Inspection Vehicles for $\phi 25, \phi 50, \phi 250$ Pipes," Journal of Robotics and Mechatronics, vol.12, no.3, pp.310-317, 2000.

[ 3 ] T. Takayama and S. Hirose: "Development of "Souryu I \& II" Connected Crawler Vehicle for Inspection of Narrow and Winding Space-," Journal of Robotics and Mechatronics, vol.15, no.1, pp.61-69, 2001.

[4 ] 亀川哲志, 松野文俊: “遠隔操作性を考慮した双頭へビ型レスキューロボッ ト KOHGA の開発”, 日本ロボット学会誌, vol.25, no.7, pp.10741081, 2007.

[5] 北島寞, 大須賀公一：“四面クローラ機構を有するガレキ内探索レス キューロボット MOIRA の開発”, システム制御情報学会, 第 47 回 システム制御情報学会学術講演会資料, pp.243-244, 2003.

[6] J. Borenstein, M. Hansen and A. Borrell: "The OmniTread OT-4 serpentine robot-design and performance," Journal of Field Robotics, vol.24, no.7, pp.601-621, 2007.

[ 7 ] 松野文俊, 川合徹：ねじの原理に基づく推進装置及びそれを用いた推 進ユニット, 特願 2003-293656, 2003.

[8 ] 里村章悟, 原正哉, 福島宏明, 龟川哲志, 五十嵐広希, 松野文俊: “权 じ推進へビ型ロボットのモデリングと制御”, 日本ロボット学会誌, vol.25, no.5, pp.779-784, 2007.

[9] M. Sampei, T. Tamura, T. Kobayashi and N. Shibui: "Arbitrary Path Tracking Control of Articulated Vehicles Using Nonlinear Control Theory," IEEE Trans. Cont. Sys. Tech, vol.3, pp.125-131, 1995.

[10] C. Altafini: "A Path-Tracking Criterion for an LHD Articulated Vehicle," Int. J. Robot. Res., vol.18, pp.435-441, 1999.

[11] C. Altafini: "Path Following With Reduced Off-Tracking for Multibody Wheeled Vehicles," IEEE Trans. Cont. Sys. Tech, vol.11, pp.598-605, 2003.

\section{付録 $\mathrm{A}$. 第 2 関節 $\phi_{2}$ と第 3 関節 $\phi_{3}$ の収束性}

4 章で示したように，第 1 関節の角度は式（23）の值に収束 する。したがって，ここでは

$$
\phi_{1}=\sin ^{-1} \frac{L}{2 R_{j 1}}+\alpha_{j 1}, \quad \dot{\phi}_{1}=0
$$

として $\phi_{2}$ と $\phi_{3}$ の収束性を考察する。まず, 式 (13)（A.1） より

$$
\begin{aligned}
\Phi_{2}: & =\dot{\phi}_{2}=\dot{\psi}_{3}-\dot{\psi}_{p}-\dot{\phi}_{1} \\
& =\frac{2}{L}\left\{\dot{x}_{j 2} \sin \psi_{3}-\dot{y}_{j 2} \cos \psi_{3}\right\}-\omega_{1}
\end{aligned}
$$

が成り立つ。ここで，式（19）の微分と式（7）ょり $\dot{x}_{j 2} \sin \psi_{3}-\dot{y}_{j 2} \cos \psi_{3}=\dot{x}_{j 1} \sin \psi_{3}-\dot{y}_{j 1} \cos \psi_{3}$

$$
\begin{aligned}
& -L \dot{\psi}_{2}\left(\sin \psi_{2} \sin \psi_{3}+\cos \psi_{2} \cos \psi_{3}\right) \\
= & R_{j 1} \omega_{1} \sin \left(\psi_{3}-\left(\psi_{p}+\alpha_{j 1}\right)\right) \\
& -L \omega_{1} \cos \phi_{2}
\end{aligned}
$$

であるので, 式（A.2）に代入すると

$$
\Phi_{2}=\frac{2 \omega_{1}}{L}\left\{R_{j 1} \sin \left(\phi_{1}+\phi_{2}-\alpha_{j 1}\right)-L \cos \phi_{2}\right\}-\omega_{1}
$$

を得る，さらに，式（A.1）の $\phi_{1}$ を式（A.3）に代入すると

$$
\begin{aligned}
\Phi_{2} & =\frac{2 \omega_{1}}{L}\left\{R_{j 1} \sin \left(\sin ^{-1} \frac{L}{2 R_{j 1}}+\phi_{2}\right)-L \cos \phi_{2}\right\}-\omega_{1} \\
& =\frac{2 \omega_{1}}{L}\left\{R_{j 1} \cos \left(\sin ^{-1} \frac{L}{2 R_{j 1}}\right) \sin \phi_{2}-\frac{L}{2} \cos \phi_{2}\right\}-\omega_{1} \\
& =\frac{2 \omega_{1}}{L}\left\{\sqrt{R_{j 1}^{2}-\frac{L^{2}}{4}} \sin \phi_{2}-\frac{L}{2} \cos \phi_{2}\right\}-\omega_{1} \\
& =\frac{2 \omega_{1}}{L} R_{j 1} \sin \left(\phi_{2}+\alpha_{j 2}\right)-\omega_{1}
\end{aligned}
$$

が成立する。ただし

$$
\alpha_{j 2}=\cos ^{-1} \frac{1}{2 R_{j 1}} \sqrt{R_{j 1}^{2}-\left(\frac{L}{2}\right)^{2}}=-\sin ^{-1} \frac{L}{2 R_{j 1}}
$$

である. よって， $R_{j 1}>L>0$ より，一般性を失わず $-\pi / 2<$ $\alpha_{j 1}<0$ とする. このとき, 正定行列 $V_{2}=\Phi_{2}^{2} / 2$ に対して

$$
\dot{V}_{2}=\Phi_{2} \dot{\Phi}_{2}=\Phi_{2}^{2} \frac{2 R_{j 1} \omega_{1}}{L} \cos \left(\phi_{2}+\alpha_{j 2}\right) .
$$

が成り立つ. 関節角の可動範囲により $-\pi / 2 \leq \phi_{2} \leq \pi / 2$ であ るので, 式 (22) の場合と同様の議論により

$$
\Phi_{2}=\frac{2 \omega_{1}}{L} R_{j 1} \sin \left(\phi_{2}+\alpha_{j 2}\right)-\omega_{1} \rightarrow 0
$$

となる。 よって， $\phi_{2}$ は可動範囲内で以下のように収束する.

$$
\phi_{2} \rightarrow \sin ^{-1} \frac{L}{2 R_{j 1}}-\alpha_{j 2}=2 \sin ^{-1} \frac{L}{2 R_{j 1}}
$$

次に, $\phi_{2}=2 \sin ^{-1} L /\left(2 R_{j 1}\right), \dot{\phi}_{2}=0$ とすると, 同様の手 順で $\Phi_{3}:=\dot{\phi}_{3}=\dot{\psi}_{4}-\dot{\psi}_{p}-\dot{\phi}_{1}-\dot{\phi}_{2}=\left(2 \omega_{1} R_{j 1} / L\right) \sin \left(\phi_{3}+\right.$ $\left.\alpha_{j 2}\right)-\omega_{1}$ が成り立つ.これは, 式 (A.4) と同じ形となって いるので, 式 (A.8) と同様に $\phi_{3} \rightarrow 2 \sin ^{-1} L /\left(2 R_{j 1}\right)$ が成り 立つ。 


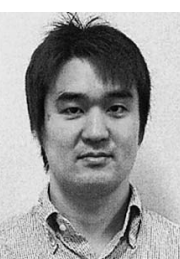

福島宏明 (Hiroaki Fukushima)

2001 年京都大学大学院情報学研究科博士課程修了 1999 年から 2004 年まで日本学術振興会特別研究 員, 2004 年より電気通信大学助手, 2009 年より京 都大学大学院工学研究科 (機械理工学専攻) 助教と なり，現在に至る。主に，システム同定，ロバスト制 御の研究に従事. 計測自動制御学会, システム制御 情報学会, IEEE の会員. 博士 (情報学)。（日本ロボット学会正会員）

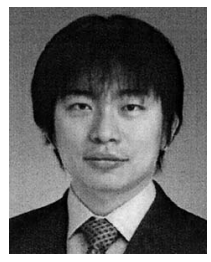

亀川哲志（Tetsushi Kamegawa）

2004 年東京工業大学大学院総合理工学研究科博士 課程修了．同年，イタリア・ローマ大学客員研究員， NPO 国際レスキューシステム研究機構研究員を経 て, 2006 年より岡山大学大学院自然科学研究科助 手, 2007 年同助教, 2008 年同講師となり, 現在に 至る。ヘビ型ロボット, レスキューロボットの研究 に従事. 日本機械学会, 計測自動制御学会の会員. 博士 (工学).

（日本ロボット学会正会員）

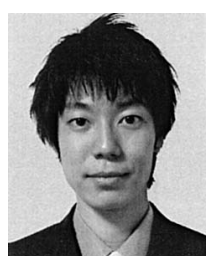

学).

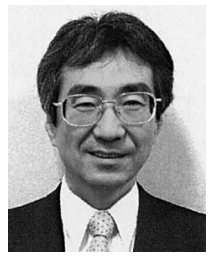

松野文俊（Fumitoshi Matsuno）

1986 年大阪大学大学院基礎工学研究科博士課程修 了. 大阪大学, 神戸大学, 東京工業大学, 電気通信 大学を経て 2009 年より京都大学大学院工学研究科 (機械理工学専攻) 教授となり現在に至る。2002 年 より NPO 国際レスキューシステム研究機構理事, 2005 年より副会長. 主に, ロボティクス・制御工 学・レスキュー学に関する研究に従事. 1989 年度日本ロボット学会 研究奖励賞, 1993 年度システム制御情報学会論文賞, 1997 年度消防 防災科学論文賞 (消防庁長官表彰), 2001 年度, 2006 年度計測自動 制御学会論文賞, 2001 年度同学会武田賞, 2006 年度船井情報科学振 興賞などを受賞. IEEE, 日本機械学会, GIS 学会, 情報処理学会な どの会員. 工学博士。

(日本ロボット学会正会員) 